\title{
Interspecific differences in the efficiency and photosynthetic characteristics of the symbiosis of "solarpowered" Nudibranchia (Mollusca: Gastropoda) with zooxanthellae
}

\author{
Ingo Burghardt ${ }^{1}$ and Heike Wägele ${ }^{2}$ \\ ${ }^{1}$ Lehrstuhl für Spezielle Zoologie, Ruhr-University Bochum, Germany \\ Ingo.Burghardt@rub.de \\ ${ }^{2}$ Institut für Evolutionsbiologie und Ökologie, University of Bonn, Germany \\ HWaegele@evolution.uni-bonn.de
}

\begin{abstract}
In this study the photosynthetic performance and efficiency of the symbiosis of different species of the Cladobranchia (Nudibranchia) with zooxanthellae (Dinophyceae) of the genus Symbiodinizm Freudenthal, 1962 is investigated. The species studied include members of the Aeolidoidea (Aeolidiella alba Risbec, 1928, Limenandra nodosa Haefelfinger and Stamm, 1958, Phestilla lugubris (Bergh, 1870) Phyllodesmium briareum (Bergh 1896), Spurilla australis Rudman, 1982), one member of the former Arminoidea (Dermatobranchus sp.) and one of the Dendronotoidea (Melibe cf. bucephala Bergh, 1902). Long term cultivation under starving conditions indicates a symbiotic relationship with zooxanthellae in all investigated species by means of Pulse Amplitude Modulated Fluorescence. The data taken by a DivingPAM (submersible Pulse Amplitude Modulated Fluorometer) indicate interspecific differences in the ability to retain photosynthetic active zooxanthellae and suggest different stages in the evolution of this symbiosis represented by different species of Nudibranchia. The efficiency of the symbiotic relationship can be correlated with morphological adaptations, especially the branching system of the digestive gland. Interspecific differences in the photosynthetic characteristics suggest different involved types or strains of Symbiodinium, depending on the specific food source and its distribution in geographic range and depth.
\end{abstract}

Key words: Nudibranchia, mutualistic symbiosis, Pulse Amplitude Modulated Fluorescence, zooxanthellae, Symbiodinium, photosynthesis.

\section{INTRODUCTION}

The mutualistic symbiosis of different clades of the Nudibranchia with zooxanthellae (unicellular dinoflagellates of the genus Symbiodinium Freudenthal, 1962) was already described by Rousseau (1934, 1935). Assignment to the genus Symbiodinium with the known 5 clades (see LaJeunesse 2001, Rodriguez-Lanetty 2003, Ulstrup and van Oppen 2003) was verified by investigating several nudibranchs belonging to the family Facelinidae by molecular means (Melkonian pers. comm.). Other taxa ("zoochlorellae" like e.g., Carteria Diesling 1866, Prochloron (Lewin 1975)) cultivating a symbiotic relationships with marine invertebrates (e.g., didemnid tunicates) are in nudibranchs only known from the temperate species Aeolidia papillosa (Linnaeus, 1761) although this symbiosis does not seem to be stable (McFarland and Muller-Parker 1993).

The zooxanthellae are housed inside the cells of the digestive gland. Generally the nudibranchs take up Symbiodinium through their prey, mostly by feeding on soft corals, in some cases also hard corals. Some nudibranchs, e.g., Melibe Rang, 1829, do not feed on cnidarians and the source of the zooxanthellae is still not verified. The advantages of this mutualistic relationship were already discussed by different authors. The incorporation of zooxanthellae offers a cryptic appearance (Rudman 1987, Wägele and Johnsen 2001, Burghardt and Wägele 2004, Burghardt et al., in press) and photosynthetic products to the involved nudibranch (Hoegh-Guldberg and Hinde 1986, HoeghGuldberg et al. 1986, Rudman 1991, Wägele and Johnsen 2001, Burghardt and Wägele 2004, Burghardt et al., in press). These additional nutrients allow them to survive periods of food shortage or even without their documented food (Burghardt and Wägele 2004, Burghardt et al., in press).

In the past, zooxanthellae inside nudibranchs were mainly detected by histological and ultrastructural investigations (Kempf 1984, Rudman 1981a,b, 1982a,b, 1991; Marin and Ros 1991; Wägele 
and Johnsen 2001). Wägele and Johnsen (2001) and Burghardt et al. (in press) have already discussed that the existence of Symbiodinium inside the digestive gland cells does not necessarily prove a symbiotic relationship with the host. Wägele and Johnsen (2001) were the first who introduced the now established method of using a PAM ("Pulse Amplitude Modulated Fluorometer") to distinguish digested from photosynthetically active zooxanthellae in situ inside seaslugs. Burghardt and Wägele (2004) and Burghardt et al. (in press) performed long term experiments with "solarpowered" nudibranchs (Wägele and Johnsen 2001) of the genus Phyllodesmium Ehrenberg, 1831 and Pteraeolidia ianthina (Angas, 1864) and showed intra- and interspecific differences in the efficiency of the symbiosis by means of PAM data.

In this study we present new data from different nudibranch species belonging to different subtaxa of the Cladobranchia (Aeolidoidea, "Arminoidea" and Dendronotoidea) and discuss the efficiency and photosynthetic characteristics of their symbiosis with Symbiodinium by presenting the results of long term starvation experiments including PAM data.

\section{MATERIAL AND METHODS}

For this study, nudibranchs from different localities in the Indopacific and the Red Sea were sampled. Phyllodesmium briareum was collected at Cobia Hole, Lizard Island (Great Barrier Reef, Australia) at a depth of $16 \mathrm{~m}$ on Briareum violacea in July 2002. Phestilla lugubris was collected at Loomis Reef, Lizard Island under a Porites coral in $0.5 \mathrm{~m}$ depth in August 2004. Melibe cf. bucephala Bergh, 1902, Aeolidiella alba Risbec, 1928, Spurilla australis Rudman, 1982 and Limenandra nodosa Haefelfinger and Stamm, 1958 were collected on a field trip to Dahab (Gulf of Aquaba, Red Sea, Egypt) in May 2003. All Red Sea specimens were collected at Dahab lagoon, in shallow water from 0.5 to $1.5 \mathrm{~m}$ depth between coral rubble. Dermatobranchus sp. was collected near Pulau Talise, north of Sulawesi (Indonesia) in July 2003. This specimen was found under coral rubble in about $1 \mathrm{~m}$ depth.

Phyllodesmium briareum and Phestilla lugubris were kept under natural moderate light conditions (up to a maximum of $\sim 350 \mu \mathrm{mol}$ quanta $\mathrm{m}^{-2} \mathrm{~s}^{-1}$ at solar noon) for the whole time of the experiments at the Lizard Island Research Station (LIRS; for details see Burghardt et al., in press). Natural light conditions means natural light climate conditions in which irradiance, spectral irradiance and photoperiod are driven by the sun's position (sun angle), clouds, the extinction coefficient of water and depth. All Red Sea specimens were kept in natural light conditions (shade) during the first 10-14 days and after transfer to Germany kept under controlled artificial light conditions (up to a maximum of 70 $\mu \mathrm{mol}$ quanta $\left.\mathrm{m}^{-2} \mathrm{~s}^{-1}\right)$ in the laboratory at the RuhrUniversity Bochum. Dermatobranchus sp. was kept in the shade (under a roof, $\sim 200 \mu \mathrm{mol}$ quanta $\mathrm{m}^{-2} \mathrm{~s}^{-1}$ ) on Pulau Bunaken (Bunaken Islands, Indonesia). All specimens were kept without their documented food under starvation conditions to prevent the uptake of fresh zooxanthellae. A Pulse Amplitude Modulated Fluorometer (Diving-PAM, Walz, Germany) was used to detect in vivo photosynthetic activity of zooxanthellae in the investigated nudibranchs by measuring the fluorescence emitted by photosystem II (PSII) of chlorophyll a. This allows distinguishing between active photosynthetic zooxanthellae and digested ones inside the nudibranch (Wägele and Johnsen 2001; Burghardt and Wägele 2004; Burghardt et al., in press).

Measurements of the maximum fluorescence yield $\left(\Phi_{\text {IIe-max }}\right)$ were taken in darkness. $\Phi_{\text {Ie-max }}$ was plotted versus time in diagrams in order to show how long the zooxanthellae are able to stay photosynthetically active inside the nudibranch and to detect possible interspecific differences.

Except for Dermatobranchus sp. and Phestilla lugubris, all specimens were exposed to different irradiances of natural sunlight between 0 and 1500 $\mu \mathrm{mol}$ quanta $\mathrm{m}^{-2} \mathrm{~s}^{-1}$ for measuring the operational quantum yield $\left(\Phi_{\mathrm{Ie}}\right)$ and obtaining photosynthesis versus irradiance curves (P-E curves). The P-Ecurves and the resulting values $\left(\mathrm{P}_{\max }, \mathrm{E}_{\mathrm{k}_{1}} \alpha\right)$ were analysed by the statistics software Kaleidagraph 3.6. For the calculations the following equation was used (for further details see Wägele and Johnsen 2001):

$\mathrm{P}=\mathrm{P}_{\max }{ }^{*}\left(1-\exp \left(-\alpha^{*} \mathrm{E} / \mathrm{P}_{\max }\right)\right)$

$\mathrm{P}=$ photosynthetic rate at a given actinic irradiance, $\mathrm{P}=\Phi_{\mathrm{Ile}} \cdot \mathrm{E}$ where:

$P=\Phi_{\text {IIe }}[\mathrm{mol}$ charge separation $\cdot$ mol quanta absorbed $\left.{ }^{-1}\right] \cdot E\left[\mu\right.$ mol quanta $\left.\mathrm{m}^{-2} \mathrm{~s}^{-1}\right]$

$\Phi_{\text {IIe }}=$ operational quantum yield

$\mathrm{P}_{\max }=$ maximum photosynthetic rate (same units as P)

$\alpha$ maximum light utilization coefficient $\left(\alpha=\left(\Phi_{\mathrm{Ie}} \cdot \mathrm{E}\right)\right.$ $\cdot \mathrm{E}^{-1}$ )

$\mathrm{E}=$ Irradiance $\left(\mathrm{PAR}, 400-700 \mathrm{~nm} ;\left[\mu \mathrm{mol}\right.\right.$ quanta $\mathrm{m}^{-2}$ $\left.\left.\mathrm{s}^{-1}\right]\right)$ $\mathrm{E}_{\mathrm{k}}=\mathrm{P}_{\text {max }}$
$\left.\mathrm{m}^{-2} \mathrm{~s}^{-1}\right]$

For curve linear regression the Webb equation was used (Webb et al. 1974). For methodological details see Wägele and Johnsen (2001) and Burghardt et al. (in press). After the long term experiments (and before their natural death) all specimens were preserved in formalin/seawater for later histological investigations.

\section{RESULTS}

Comparisons of the maximum yield of 

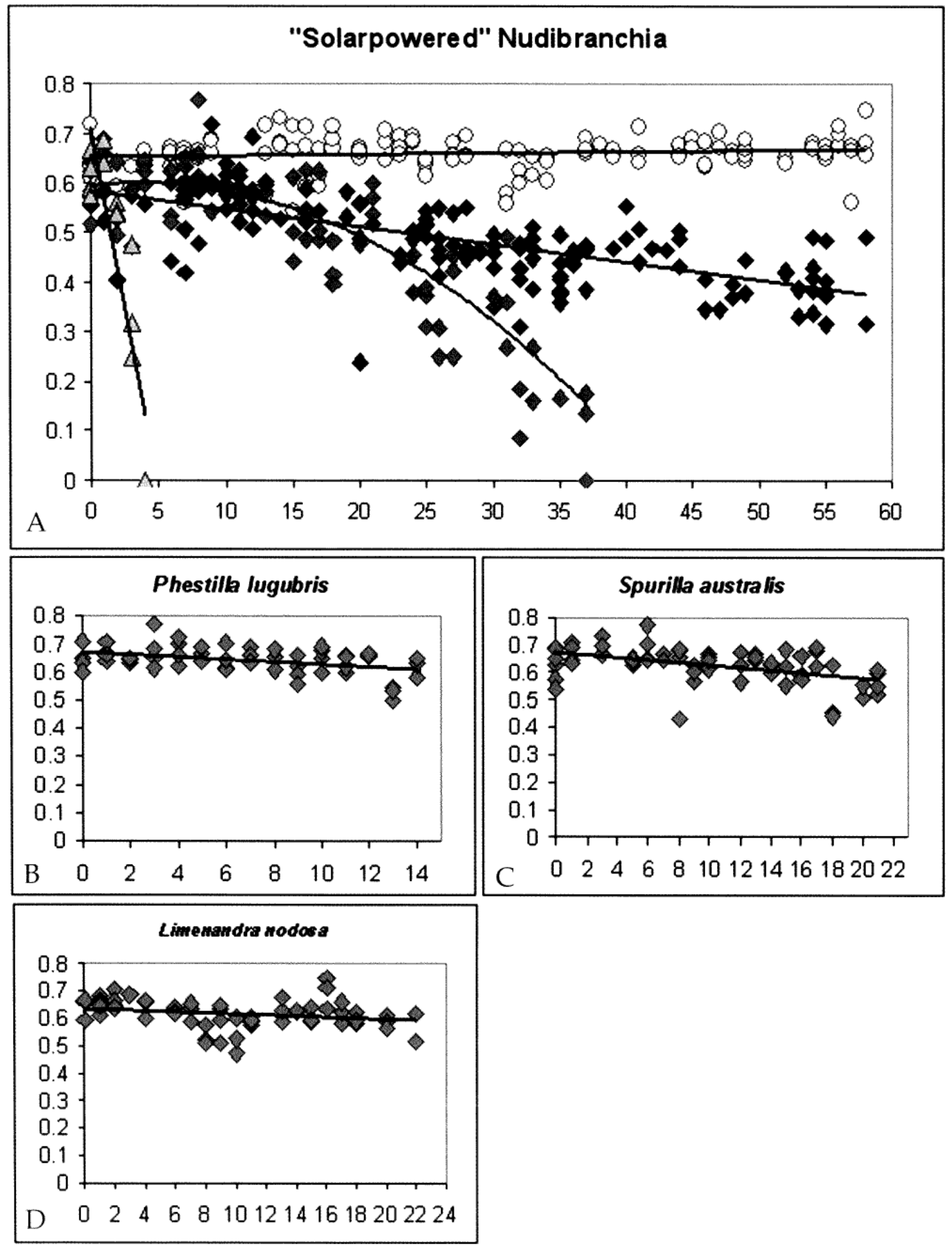

Figure 1 Yield of photosynthesis $\left(\mathrm{F}_{(1 \mathrm{k} \cdot \mathrm{mot}}\right.$ ) versus time (number of cultivation days under starving conditions in light). A: Melibe of. bucephala (O white circles); Phyllodesminu briareum ( $\bullet$ dark diamonds); Acolidiella alba ( $\diamond$ light grey diamonds, ) and Dermatobranchus sp. (A light grey triangles). B: Phestilla lugubris. C: Spurilla australis. D: Limchandra nodosa. Please note the different scales for the number of starvation days in B, C and D. 
photosynthesis $\left(\Phi_{\text {lle max }}\right.$ ) for the different species of Nudibranchia indicate interspecific differences in the efficiency of the symbiotic relationship (Figure 1). The dendronotoid Melibe cf. bucephala shows no decrease in the maximum yield for at least 60 days. $\Phi_{\text {Ile-max }}$ was constant between values of 0.6 and 0.7 . Further cultivation of this specimen for 8 months showed also no decrease in maximum yield (Burghardt and Wägele, in preparation). The yield values of the aeolid species Phyllodesmium briareum also maintain a high level for the whole time, but decrease slowly from 0.65 in the beginning to an average of 0.4 after almost 60 days of starvation. In contrast to $P$. briareum, the $\Phi_{\text {IIe-max }}$ values of the aeolid Aeolidiella alba decrease from an average of 0.65 in the beginning to approximately 0.2 after 37 days without food.

In the "arminoid" Dermatobranchus sp. the decrease in the maximum yield is even more dramatic: $\Phi_{\text {lle-max }}$ drops from 0.7 to 0 within 5 days of starvation.

Three other aeolid species measured over a time period of 14 to 22 days, namely Phestilla lugubris (Figure 1B), Spurilla australis (Figure 1C) and Limenandra nodosa (Figure 1D), obtained a gradual decrease in $\Phi_{\text {Ile-max }}$ versus time, similar to the one observed in Phyllodesmium briareum. In Limenandra nodosa the decrease of $\Phi_{\text {Ite-max }}$ is slightly less than in Phestilla lugubris and Spurilla australis.

The diagrams of photosynthesis versus irradiance (P-E-diagrams) for each species are shown in Figure 2. Apart of the curve of Aeolidiella alba all other curves reach the plateau below $400 \mu \mathrm{mol}$ quanta $\mathrm{m}^{-2}$ $\mathrm{s}^{-1}$ (Figure 2). The resulting $E_{k^{\prime}} \alpha$ and $P_{\operatorname{mix}}$ values of all investigated species and their known food sources, except for Dermatobranchus sp. and Phestilla lugubris, are listed in Table 1. Except for Melibe cf. bucephala, all species in Table 1 feed on different anthozoans (Table 1). Compared to the values of the other species, the $\alpha$ value of Melibe cf. bucephala is high and the one of Phyllodesmium briareum is low. The $P_{\text {max }}$ and $E_{k}$ values of $P$. briaretm are also comparably low. In contrast, Aeolidiella alba shows very high $P_{\max }$ and $E_{k}$ values. The values of Limenandra nodosa, Melibe cf. bucephala and Spurilla australis are lower but still on a high level (Table 1).

\section{DISCUSSION}

By measuring the emitted fluorescence of PSII, the PAM data in the present study prove photosynthetic activity inside all investigated species of nudibranchs at least for some days (Figure 1). The $\Phi_{\mathrm{Ile} \text {-max }}$ between 0.5 and 0.8 indicates a well functioning photosynthesis inside the involved zooxanthellae (Wägele and Johnsen 2001; Burghardt et al., in press). However the results of the long term experiments show interspecific differences in the slugs in $\Phi_{11 \mathrm{e}-\mathrm{max}}$ values over time and therefore differences in retaining photosynthetic active cells of Symbiodinium inside their body. Kempf (1991: 83-84) defined different stages and types of a symbiosis between nudibranchs and zooxanthellae depending on the retention time and the fate of the zooxanthellae: Type I represents non-symbiotic associations in which the nudibranch feeds on symbiotic cnidarians and digests the symbiotic algae as prey item. Type II is also non-symbiotic and includes coincidental associations in which the zooxanthellae are ingested and passed undigested through the gut. In Type III the symbionts are incorporated into the nudibranch's cells, stay alive for a period of time and are digested afterwards. Type IV represents

Table 1 Photosynthetic characteristics and food sources of Aeolidiella alba, Limenandra nodosa, Melibe cf. bucephala, Phyllodesmium briareum and Spurilla australis. Photosynthetic characteristics are calculated by Kaleidagraph 3.6, based on measurements with a Diving-PAM (Walz, Germany). Food sources are taken from literature

\begin{tabular}{|c|c|c|c|c|c|}
\hline Species & $\alpha$ & $\mathbf{P}_{\max }$ & $\begin{array}{l}\mathbf{E}_{k} \\
{[\mu \mathrm{mol}} \\
\left.\text { quanta } / \mathrm{m}^{-1} \mathrm{~s}^{-2}\right]\end{array}$ & Foodsource & Reference \\
\hline Acolidiella alba & 0.63 & 135 & 214 & $\begin{array}{l}\text { Acontiate white sea } \\
\text { anemones }\end{array}$ & Gosliner 1987b \\
\hline Limenandra nodosa & 0.68 & 82 & 120 & $\begin{array}{l}\text { Bunodeopsis strumosa, } \\
\text { Bunodeopsis ssp. }\end{array}$ & $\begin{array}{l}\text { Navoni 1973, Schmekel } 1968 \text {, } \\
\text { Schmekel and Portman } 1982\end{array}$ \\
\hline Melibe cf. bucephala & 0.89 & 92 & 103 & $\begin{array}{l}\text { Amphipoda, } \\
\text { Gammaridae, } \\
\text { Caprellidae }\end{array}$ & $\begin{array}{l}\text { Debelius 2002, Crossland and } \\
\text { Kempf 1985, Kempf 1984, Gosliner } \\
\text { and Smith } 2003\end{array}$ \\
\hline Phyllodesminm briareum & 0.46 & 24 & 52 & Briareum violacea & $\begin{array}{l}\text { Rudman 1991, Wägele and Johnsen } \\
\text { 2001, Burghardt } e t \text { al., in press }\end{array}$ \\
\hline Spurilla australis & 0.76 & 105 & 138 & $\begin{array}{l}\text { Sea anemones (e.g. } \\
\text { Cricophorus nutrix) and } \\
\text { related cnidarians }\end{array}$ & $\begin{array}{l}\text { Willan and Coleman } 1984, \\
\text { Rudman } 1982 a\end{array}$ \\
\hline
\end{tabular}



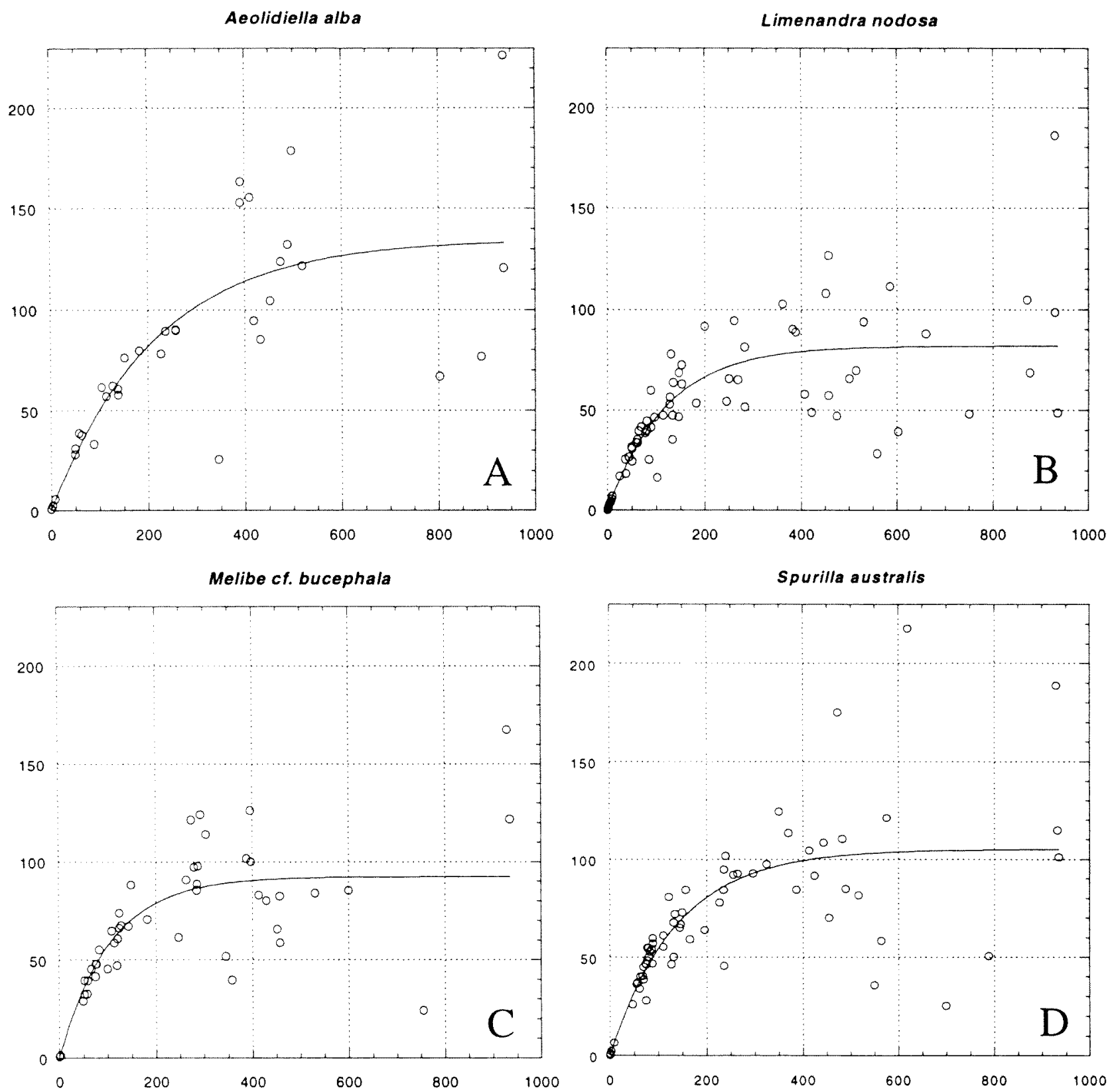

P hyllodesmium briareum

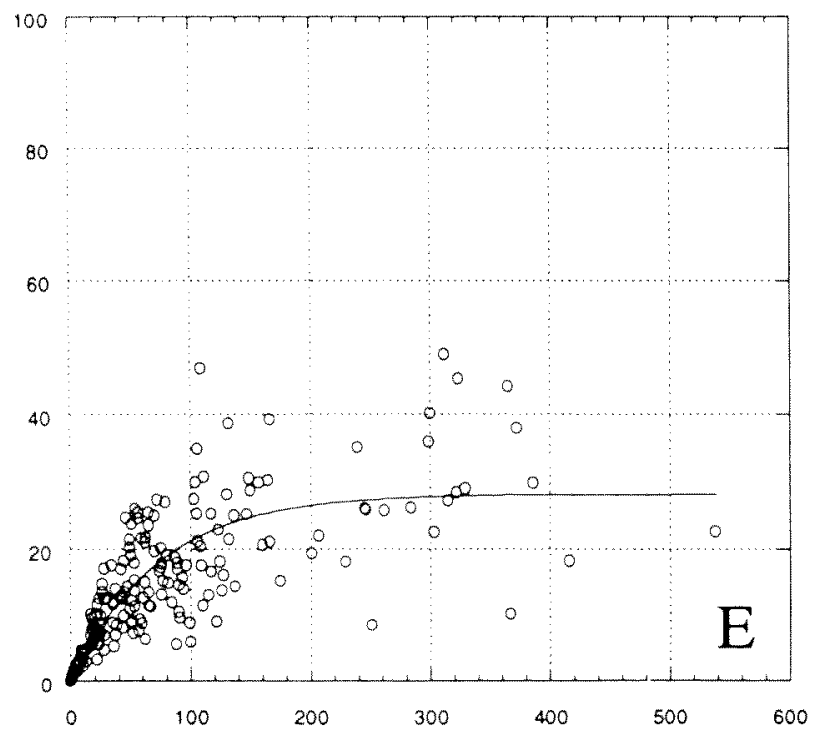

Figure 2 Photosynthetic rate $\left(\mathrm{P}=\Phi_{11 \mathrm{e}}{ }^{*} \mathrm{E}, \mathrm{y}\right.$-axis $)$ versus irradiance $\left(E ;\right.$; $\mu$ mol quanta $\left.\mathrm{m}^{-2} \mathrm{~s}^{-1}\right], x$-axis) of different species of Nudibranchia. A: Aeolidiella alba. B: Limenandra nodosa. C: Melibe cf. bucephala. D: Spurilla australis. E: Phyllodesmium briareum. Please note different scales for $\mathrm{P}$ and $\mathrm{E}$ in Phyllodesmium briareum. 
primitive mutualistic symbioses in which the symbionts are incorporated in a healthy stage and are defaecated in healthy condition. Type $\mathrm{V}$ includes advanced mutualistic associations in which cells, tissues or organs are specialized to house symbionts. Type VI represents the most advanced symbiosis, in which the host acquires its symbionts de novo and has specialized cells or organs for symbiont maintenance. The maintenance of high values in Melibe cf. bucephala (Dendronotoidea) for the whole time of the experiments suggests a highly effective mutualistic symbiosis, similar to the one observed in Pteraeolidia ianthina (Kempf 1984; Burghardt et al., in press). The zooxanthellae are able to proliferate inside the nudibranch. By applying the ${ }^{14} \mathrm{C}$-method, Kempf (1984) has shown for Melibe pilosa Pease, 1860 and an unidentified Melibe, that there is a transfer of photosynthetic products translocated from the symbionts (zooxanthellae) to the host. But M. pilosa was not able to survive more than 30 days under starvation conditions (Kempf 1984). Kempf (1991) assigned $M$. pilosa and $M$. megaceras to the highest type (VI), which we would confirm also for $M$. cf. bucephala according to our results. We observed a high grade of branching of the digestive gland in Melibe cf. bucephala. Extensive branching of the digestive gland enlarges the surface area for storage of zooxanthellae and allows higher photosynthetic light absorption and utilization (Rudman 1991; Burghardt et al., in press). The cells of the fine branches of the digestive gland are filled with zooxanthellae (unpublished data) and give the transparent animal a brownish appearance. Therefore our PAM data confirm the assumption of Rudman (1991) that there is a correlation between the branching grade of the digestive gland and the efficiency of a symbiotic relationship. This was already confirmed for Phyllodesmium briareum and Pteraeolidia ianthina (Burghardt et al. in press). As already suggested by Gosliner and Smith (2003), the transparent body of some Melibe species, like in $M$. cf. bucephala, allows good light transmission to the symbionts. Additionally, the cerata are arranged in an alternating pattern. That minimizes shading and optimizes control of light intensity (Gosliner and Smith 2003). The combination of transparency and the brownish colour originating from the zooxanthellae offers crypsis to the animal, another evolutionary advantage. Melibe feeds on prey, like small crustaceans that do not contain Symbiodinitum at all (Table 1). Therefore we assume that $M$. cf. bucephala recruits its zooxanthellae from the free water column.

Phyllodesmium briareum (Aeolidoidea, Facelinidae) also shows high $\Phi_{\text {II-max }}$ values over 9 weeks (Figure 1A). Rudman (1991) suggested that this species has a highly effective symbiosis with Symbiodinium. This was confirmed by Burghardt et al. (in press) in long term experiments but compared to another facelinid, Pteracolidia ianthina (see Burghardt et al., in press) and Melibe cf. bucephala (present study), the values slightly decrease over time. The decrease of the $\Phi_{\text {Ile-max }}$ values in starving animals indicates that the portion of still photosynthetically active zooxanthellae is getting smaller and the animal is not able to keep all of them fully photosynthetic active over a long period. According to our results, we assign $P$. briareum to type $V$ of Kempf's classification. The branching grade of the digestive gland in Phyllodesmium briareum is quite high and similar to the one of Pteraeolidia ianthina and Melibe cf. bucephala. Therefore, this feature seems to be unlikely the reason for the interspecific variation of zooxanthellae retention. Further histological and ultrastructural investigations need to be done to clarify the retention system within the cells.

The quicker decrease of $\Phi_{\text {nle-max }}$ values of Acolidiella alba (Aeolidoidea, Aeolidiidae) with nearly no yield of photosynthetic activity after 40 days indicate either dying or digested zooxanthellae (Wägele and Johnsson 2001, Burghardt et al. in press). This condition represents type III. Until now it was not known that $A$. alba houses zooxanthellae, although Rudman (1982a) suspected that symbiosis may also be present in some species of Aeolidiella. Zooxanthellae are demonstrated in Aeolidiella alderi (Cocks, 1852) (Graham 1938, Marin and Ros 1991), Aeolidiella glauca (Alder and Hanckock, 1845) (Rousseau 1934, 1935) and Aeolidiella croisicensis Labbe, 1923 (Rousseau 1935) only by histological means. That does not necessarily prove a symbiosis. The grade of branching of the digestive gland is much less in Aeolidiella alba than e.g., in Melibe cf. bucephala and Phyllodesmitum briareum.

Limenandra nodosa and Spurilla australis, both members of the Aeolidiidae, show almost no decrease of the $\Phi_{\text {Ile-max }}$ values over 22 days under starving conditions (Figure 1C, D). Without long term data we can only speculate, that the yield values could decrease in a similar way to the ones of Aeolidiella alba. As in A. alba, the digestive gland of $L$. nodosa does not branch to the same extent as that of Melibe cf. bucephala or Phyllodesmium briareum. Kempf (1984) states that Limenandra nodosa (named as Baeolidea nodosa) maintains a symbiosis with zooxanthellae but there are no data presented and further investigations are needed. Spurilla australis has complex digestive gland ramifications in the body wall, rhinophores, oral tentacles and cerata (Rudman 1982a). The cerata are partially flattened and the digestive gland inside the cerata is highly branched. Zooxanthellae are only found in the digestive gland immediately below the cnidosac and down the anterior edge of each ceras - these regions are least likely to be shaded by other cerata (Rudman 1982a). Therefore these structures can be interpreted as adaptations for housing 
Symbiodinium. Kempf (1991) assigned Spurilla australis to type $\mathrm{V}$ of his classification, representing an advanced mutualistic association for this species.

Phestilla lugubris is the only member of the Tergipedidae (Aeolidoidea) so far (Rudman 1982a), that houses zooxanthellae as symbionts. At least for 14 days the specimens investigated show photosynthetic activity, indicated by high $\Phi_{\text {Ite-max }}$ values, on a constant high level (Figure 1B). Harris (1975) described photosynthetic activity continuing in the zooxanthellae inside the digestive gland of $P$. lugubris, without mentioning the methods applied. According to Rudman (1981) there are no branches of the digestive gland in the notum, body and foot in this species. The digestive gland inside the cerata contains nodules and lobules and is not very branched. Rudman (1981a) also observed that all parts of the ingested coral tissue are digested. In a later study Rudman (1982a) classified P. lugubris as a "facultative symbiont with zooxanthellae". According to him there are two different types of $P$. lugubris: either with or completely without zooxanthellae. Kempf (1991) assigned P. lugubris to type III of his classification. Our PAM data do not contradict his assumptions, but long term experiments are needed.

Dermatobranchus sp., a member of the Arminidae (paraphyletic "Arminoidea", see Wägele and Willan 2000 ), shows a steep slope of the $\Phi_{\text {חe-max }}$ values with no photosynthetic activity measurable after 5 days of cultivation. Wägele and Johnsen (2001) investigated Dermatobranchus semistriatus Baba, 1949 , by histological means and found unhealthy looking zooxanthellae, indicating disintegration prior to ingestion in the glandular cells. An allocation to type I or II seems likely for these two species. On the other hand, Wägele and Johnsen (2001) demonstrated that the digestive gland of another two undescribed species of Dermatobranchus is highly branched, with fine tubules and "carrier cells" (Kempf 1984) containing many healthy zooxanthellae. Similar morphological structures were also found in Pteraeolidia ianthina. The assumption of the authors that these two Dermatobranchus species have a highly evolved mutualistic symbiosis still has to be checked by investigations with the PAM.

Evidence of interspecific differences is also given by the photosynthetic characteristics of the zooxanthellae associated with nudibranchs (Table 1, Figure 2): Low values of $P_{\max }$ and $E_{k}$ indicate low light adapted/ acclimated photosynthetic active organisms, high values indicate the opposite (Wägele and Johnsen 2001; Burghardt et al. in press). Thus low $\alpha$ and $P_{\max }$ values indicate shade acclimated cells that in fact are efficient in light harvesting which is also indicated by low $E_{k}$ values. These data presented here match the locality where the investigated species have been found. Except for Phyllodesmium briareum, all species studied were found in shallow to intertidal waters exposed to high irradiances. The $\mathrm{P}_{\max ^{\prime}} \mathrm{E}_{\mathrm{k}}$ and $\alpha$ values measured in these species indicate high light adapted zooxanthellae. $P$. briareum and its food source Briareum violacea were found in deeper waters (16m depth) and our PAM data confirm that there is a different light sensitive type of Symbiodinium involved. At least seven different phylogenetic clades or strains of Symbiodinium are distinguished in literature, based on data on ribosomal DNA (LaJeunesse 2001, RodriguezLanetty 2003). Five of these clades are known to occur in corals. Unfortunately there are no detailed investigations about Symbiodinium in octocorals, or actiniids, the major food source of many solar powered nudibranchs (see Table 1), and almost nothing is known about the composition in seaslugs. Although some studies have found a lack of correlation between Symbiodinium phylotypes and photo-physiology, the distribution of zooxanthellae in some coral species correlates with light intensity and quality on different spatial scales (Savage et al. 2002). Light intensity and spectral composition are thus suggested to affect the composition of the zooxanthellae community within individual coral colonies (Ulstrup and van Oppen 2003). Future studies on the composition of zooxanthellae within the slugs, compared to their food sources, will help to elucidate selection and physiology of the relationship between these organisms and will allow to address the question, whether this mutualistic symbiosis is a key character which might have enhanced species radiation in these taxa, as was suspected by Wägele (2004).

\section{ACKNOWLEDGEMENTS}

We would like to thank our diving and collecting companions on Lizard Island (Australia), Dahab (Egypt) and Sulawesi (Indonesia): Michael Berumen (Townsville), Gilianne Brodie (Townsville), Dirk Eheberg (Munich), Michael Schrödl and Rosana Carvalho-Schrödl (Munich), Enrico Schwabe (Munich), Verena Vonnemann (Bochum) and Wolfgang Wägele (Bonn). Furthermore we thank Geir Johnsen (Trondheim) and Jussi Evertsen (Trondheim) for discussing results on PAM data. We also thank the staff of the Faculty of Fisheries and Marine Science at the Sam Ratulangi University Manado (Sulawesi, Indonesia), especially Gustaf Mamangkey, Fontje Kaligis and Grevo Gerung. Our special thanks go to the directors of the Lizard Island Research Station, Anne Hoggett and Lyle Vail for their helpful support and creating a friendly atmosphere at this station. We also thank Michael Melkonian (Cologne) for discussing aspects of the phylogeny of Symbiodinium. This study was 
funded by the German Science Foundation (SSP 1127 "Adaptive Radiation - Origin of biological Diversity": Wa 618/8) and "The Improving Human Potential - Transnational Access to Research Infrastructures Programme of the European Commission" in Trondheim, Norway.

\section{REFERENCES}

Burghardt, I. and Wägele, H. (2004). A new solar powered species of the genus Phyllodesmium Ehrenberg, 1831 (Mollusca: Nudibranchia: Aeolidoidea) from Indonesia with analysis of its photosynthetic activity and notes on biology. Zootaxa 596: 1-18.

Burghardt, I., Evertsen, J., Johnsen, G. and Wägele, H. (in press). Solar powered seaslugs - Mutualistic symbiosis of aeolid Nudibranchia (Mollusca, Gastropoda, Opisthobranchia) with Symbiodinium. Symbiosis.

Crossland, C.J. and Kempf, S.C. (1985). Carbon fixation and compartimentation in the zooxanthellae containing nudibranchs, Melibe pilosa and Melibe sp. Proc. $5^{\text {th }}$ Intern. Coral Reef Congr., Tahiti. 6: 125-130.

Debelius, H. (2002). Schneckenführer Indopazifik (book). Jahr Verlag, Hamburg.

Gosliner, T. M. (1987b). Nudibranchs of southern Africa, a guide to opisthobranch molluses of southern Africa, 136 pp. Sea Challengers. Monterey, California.

Gosliner, T.M. and Smith, V.G. (2003). Systematic review and phylogenetic analysis of the nudibranch genus Melibe (Opisthobranchia: Dendronotacea) with descriptions of three new species. Proceedings of the California Academy of Sciences 54: 302-355.

Graham, A. (1938). The structure and function of the alimentary canal of aeolid mollusks, with a discussion on their nematocysts. Transactions of the Royal Society of Edinburgh 59: 267-307.

Harris, L.G. (1975). Studies on the life history of two coral eating nudibranchs of the genus Phestilla. Biological Bulletin, Marine Biological Laboratory, Woods Hole 149: $539-550$.

Hoegh-Guldberg, O. and Hinde, R. (1986). Studies on a nudibranch that contains zooxanthellae. I. Photosynthesis, respiration and the translocation of newly fixed carbon by zooxanthellae in Pteraeolidia ianthina. Proceedings of the Royal Society London B 228: 493-509.

Hoegh-Guldberg, O. Hinde, R. and Muscatine, L. (1986. Studies on a nudibranch that contains zooxanthellae. II. Contribution of zooxanthellae to animal respiration (CZAR) in Pteraeolidia ianthina with high and low densities of zooxanthellae. Proceedings of the Royal Society London B 228: 511-521.

Kempf, S.C. (1984). Symbiosis between the zooxanthella Symbiodinium (Gymnodinium) microadriaticum (Freudenthal) and four species of nudibranchs. Biological Bulletin, Marine Biological Laboratory, Woods Hole 166: 110-126.

Kempf, S.C. (1991). A 'primitive' symbiosis between the aeolid nudibranch Berghia verrucicornis (A. Costa, 1867) and a zooxanthella. Journal of Molluscan Studies 57: 75-85.
LaJeunesse, T.C. (2001). Investigating the biodiversity, ecology and phylogeny of endosymbiotic dinoflagellates in the genus Symbiodinium using the ITS region: in search of a "species" level marker. Journal of Phycology 377: 886-880.

Marin, A. and Ros, J. (1991). Presence of intracellular zooxanthellae in Mediterranean nudibranchs. Journal of Molluscan Studies 57: 87-101.

Marin, A. and Ros, J. (1992). Dynamics of peculiar plantherbivore relationship: The photosynthetic ascoglosan Elysia timida and the chlorophycean Acetabularia acetabulum. Marine Biology 112: 677-682.

McFarland, F.K. and Muller-Parker, G. (1993). Photosynthesis and retention of zooxanthellae and zoochlorellae within the aeolid nudibranch Aeolidia papillosa. Biological Bulletin, Marine Biological Laboratory, Woods Hole 184: 223-229.

Navoni, L. (1973). Der chemische Sinn der Nudibranchier (Gastropoda Opisthobranchia). Revue Suisse de Zoologie 79(4):1333-1379, pls. 1-2.

Rodriguez-Lanetty, M. (2003). Evolving lineages of Symbiodinium-like dinoflagellates based on ITS1 rDNA. Molecular Phylogenetics and Evolution 28: 152168.

Rousseau, C. (1934). Sur la structure de l'epithelium hépatique de Eolidiens. Comptes Rendues Hebdomadaires Séances de l'Academie des Sciences, Paris 198: 677-679.

Rousseau, C. (1935). Histophysiologie du foie des eolidiens. Étude de leurs xanthelles. Cytologie des cellules nématophages. Archive d'Anatomie et Microscopie 31: 305-395.

Rudman, W.B. (1981a). Further studies on the anatomy and ecology of opisthobranch molluscs feeding on the scleractinian coral Porites. Zoological Journal of the Linnean Society, London 71: 373-412.

Rudman, W.B. (1981b). The anatomy and biology of alcyonarian feeding aeolid opisthobranch molluscs and their development of symbiosis with zooxanthellae. Zoological Journal of the Linnean Society London 72: 219-262.

Rudman, W.B. (1982a). The taxonomy and biology of further aeoliacean and arminacean nudibranch molluscs with symbiotic zooxanthellae. Zoological Journal of the Linnean Society London 74: 147-196.

Rudman, W.B. (1982b). A new species of Phestilla; the first record of a corallivorous aeolid nudibranch from tropical America. Journal of Zoology, London 198: 465471.

Rudman, W.B. (1987). Solar-powered animals. Natural History 10: 50-52.

Rudman, W.B. (1991). Further studies on the taxonomy and biology of the octocoral-feeding genus Phyllodesmium Ehrenberg, 1831 (Nudibranchia: Aeolidoidea). Journal of Molluscan Studies 57: 167-203.

Savage, A.M., Trapido-Rosenthal, H. and Douglas, A.E. (2002). On the functional significance of molecular variation in Symbiodinium, the symbiotic algae of Cnidaria: photosynthetic response to irradiance. Marine Ecology Progress Series 244: 27-37.

Schmekel, R. L. (1968). Ascoglossa, Notaspidea und Nudibranchia im Litoral des Golfes von Neapel. Revue Suisse de Zoologie 75(6):103-155. 
Schmekel, R. L., and Adolf Portmann. (1982). Opisthobranchia des Mittelmeeres, Nudibranchia und Saccoglossa. Fauna e flora del Golfo di Napoli 40, Monografia della Stazione Zoologica di Napoli, pp. i-viii, 1-410, pls. 1-36. Springer-Verlag, Berlin.

Ulstrup, K.E. and van Oppen, M.J.H. (2003). Geographic and habitat partitioning of genetically distinct zooxanthellae (Symbiodinium) in Acropora corals on the Great Barrier Reef. Molecular Ecology 12: 3477-3484.

Wägele, H. and Willan, R.C. (2000). Phylogeny of the Nudibranchia. Zoological Joumal of the Linnean Society 113: 83-181.

Wägele, H. and Johnsen, G. (2001). Observations on the histology and photosynthetic performance of "solarpowered" opisthobranchs (Mollusca, Gastropoda, Opisthobranchia) containing symbiotic chloroplasts or zooxanthellae. Organisms, Diversity and Evolution 1: 193-210.
Wägele, H. (2004). Potential key characters in Opisthobranchia (Gastropoda, Mollusca) enhancing adaptive radiation. Organisms, Diversity and Evolution 4: 175-188.

Webb, W. L, Newton, M. and Starr, D. (1974). Carbon dioxide exchange of Alnus rubra: A mathematical model. Oecologia 17: 281-291.

Willan, R. C., and Coleman, N. (1984). Nudibranchs of Australasia, 56 pp. Sea Australian Marine Photographic Index, Caringbah, New South Wales. 